\title{
Preparation of $\mathrm{CoFe}_{2} \mathrm{O}_{4} / \mathrm{SiO}_{2}$ Nanocomposites at Low Temperatures Using Short Chain Diols
}

\author{
Thomas Dippong, ${ }^{1}$ Erika Andrea Levei, ${ }^{2}$ and Oana Cadar $^{2}$ \\ ${ }^{1}$ Department of Chemistry and Biology, Technical University of Cluj-Napoca, North University Centre of Baia Mare, \\ 76 Victoriei Street, 430122 Baia Mare, Romania \\ ${ }^{2}$ INCDO-INOE 2000, Research Institute for Analytical Instrumentation, 67 Donath Street, 400293 Cluj-Napoca, Romania
}

Correspondence should be addressed to Erika Andrea Levei; erika.levei@icia.ro

Received 2 January 2017; Accepted 31 January 2017; Published 15 March 2017

Academic Editor: Jean-Marie Nedelec

\begin{abstract}
Copyright (C) 2017 Thomas Dippong et al. This is an open access article distributed under the Creative Commons Attribution License, which permits unrestricted use, distribution, and reproduction in any medium, provided the original work is properly cited.

The preparation of $70 \% \mathrm{CoFe}_{2} \mathrm{O}_{4} / 30 \% \mathrm{SiO}_{2}$ (wt\%) nanocomposites by sol-gel method using three short chain diols (1,2-ethanediol, 1,3-propanediol, and 1,4-butanediol) as chelators was studied. The Fourier transformed infrared spectra and X-ray diffraction patterns were used to confirm the formation of nanocomposites. The X-ray diffraction analysis showed that the chain length of the carboxylates embedded in the silica matrix influences the formation of crystallized cobalt ferrite as single phase at low temperatures. The influence of the methylene groups number in the precursors and annealing temperature on the nanocrystallite size was revealed. The stability of the obtained compounds was determined by calculation of thermodynamic parameters.
\end{abstract}

\section{Introduction}

During the last decades, the nanocomposites preparation techniques experienced a fast development as these materials have a wide range of applications [1-4]. The properties of nanoparticle-based composites are determined by the material's morphology, which depends on the nanoparticle size and distribution of the nanosized phase in matrix [5]. Cobalt ferrite based nanocomposites present unique physicochemical properties that make it an attractive material for catalysis, antenna rods, loading coils, magnetic data storage, sensors, ferrofluids, magnetooptic materials, energy conversion applications, and targeted drug delivery [1-6].

The preparation methods for $\mathrm{CoFe}_{2} \mathrm{O}_{4}$ nanoparticles require special techniques to prevent agglomeration $[7,8]$. A high number of methods have been reported previously for the preparation of $\mathrm{CoFe}_{2} \mathrm{O}_{4}$ nanoparticles, including microemulsion, thermal decomposition, reverse micelles, coprecipitation, sol-gel, mechanical alloying, combustion, and hydrothermal, electrochemical procedures, and green synthesis [9-18]. However, the sol-gel technique followed by annealing is one of the simplest, most effective, and feasible routes to produce high purity, homogeneous, and crystalline nanoparticles [19-21].

In the present study, the influence of the chelator chain length (1,2-ethanediol (1,2-ED), 1,3-propanediol (1,3-PD), and 1,4-butanediol (1,4-BD)) on the precursor formation and decomposition to obtain $70 \% \mathrm{CoFe}_{2} \mathrm{O}_{4} / 30 \% \mathrm{SiO}_{2}$ (wt\%) nanocomposites was investigated. The obtained gels were heated to $300^{\circ} \mathrm{C}$, annealed at 500,700 , and $900^{\circ} \mathrm{C}$, and characterized by thermal analysis (TG and DTA), X-ray diffraction (XRD), Fourier transformed infrared spectrometry (FTIR), scanning electron microscopy (SEM), and transmission electron microscopy (TEM).

\section{Materials and Methods}

2.1. Synthesis. The used reagents were $\mathrm{Fe}\left(\mathrm{NO}_{3}\right)_{3} \cdot 9 \mathrm{H}_{2} \mathrm{O}$ as iron source, $\mathrm{Co}\left(\mathrm{NO}_{3}\right)_{2} \cdot 6 \mathrm{H}_{2} \mathrm{O}$ as cobalt source, 1,2-ED, 1,3$\mathrm{PD}$, and 1,4-BD as chelators, tetraethyl orthosilicate (TEOS) as matrix precursor, ethanol as solvent, and $\mathrm{HNO}_{3}$. All reagents were of analytical grade and used as received without further purification. 
The sol was prepared by dissolving $\mathrm{Fe}\left(\mathrm{NO}_{3}\right)_{3} \cdot 9 \mathrm{H}_{2} \mathrm{O}$ and $\mathrm{Co}\left(\mathrm{NO}_{3}\right)_{2} \cdot 6 \mathrm{H}_{2} \mathrm{O}$ in molar ratio of $2: 1$ and the diol $\left(\mathrm{NO}_{3}{ }^{-}\right.$: diol $=1: 1$, molar ratio), at room temperature, in ethanol/ $\mathrm{HNO}_{3}$ solution. An amount of TEOS equal to $70 \%$ of the weight of $\mathrm{Fe}$ (III) and $\mathrm{Co}$ (II) nitrates was added dropwise under continuous stirring, followed by the addition of ethanol until complete dispersion. The resulting clear solution was exposed to open air for slow gelation. The gelation time was 16 days (1,2-ED), 19 days (1,3-PD), and 23 days $(1,4-\mathrm{BD})$, respectively. The gels were heated at $300^{\circ} \mathrm{C}$ for 4 hours and afterwards annealed at 500, 700, and $900^{\circ} \mathrm{C}$.

The redox reaction between the nitrates and diol (1,2$\mathrm{ED}, 1,3-\mathrm{PD}$, and 1,4-BD) with formation of the carboxylate precursors takes place according to (1).

$$
\begin{gathered}
3 \mathrm{HO}-\mathrm{C}-\mathrm{C}-\mathrm{OH}+8 \mathrm{NO}_{3}^{-}+2 \mathrm{H}^{+} \longrightarrow \mathrm{H}_{2} \\
\text { 1,2-Ethanediol (1,2-ED) }
\end{gathered}
$$

$$
\begin{aligned}
& 3 \mathrm{HO}-\mathrm{C}-\mathrm{C}-\mathrm{C}-\mathrm{OH}+8 \mathrm{NO}_{3}{ }^{-}+2 \mathrm{H}^{+} \longrightarrow{ }^{-}{ }^{-} \mathrm{C}-\mathrm{C}-\mathrm{C}^{\prime \prime}{ }^{\mathrm{O}}+8 \mathrm{NO}+10 \mathrm{H}_{2} \mathrm{O} \\
& \begin{array}{lll}
\mathrm{H}_{2} & \mathrm{H}_{2} & \mathrm{H}_{2}
\end{array} \\
& \begin{array}{lll}
\prime \prime & \mathrm{H}_{2} & \mathrm{O}^{-}
\end{array}
\end{aligned}
$$

1,3-Propanediol (1,3-PD)

Malonate precursor

$$
\begin{gathered}
3 \mathrm{HO}-\mathrm{C}-\mathrm{C}-\mathrm{C}-\mathrm{OH}+8 \mathrm{NO}_{3}{ }^{-}+2 \mathrm{H}^{+} \longrightarrow \\
\mathrm{H}_{2} \mathrm{H}_{2} \mathrm{H}_{2}
\end{gathered}
$$

1,4-Butanediol (1,4-BD)

Succinate precursor

2.2. Characterization. FT-IR spectra were recorded in transmission mode on $\mathrm{KBr}$ pellets using a Perkin-Elmer Spectrum BX II FT-IR spectrometer. XRD analysis was performed at room temperature, using a Bruker D8 Advance diffractometer using a $\mathrm{CuK}_{\alpha}$ radiation $(\lambda=1.54060 \AA)$. Thermogravimetry (TG) and Differential Thermal Analyses (DTA) were performed by a SDT Q600 type instrument from the room temperature up to $900^{\circ} \mathrm{C}$, with a rate of heating of $10^{\circ} \mathrm{C} / \mathrm{min}$, in air. For the nanocrystallites' shape and clustering, a Hitachi HD-2700 TEM equipped with digital image recording system and photographic film image with high resolution scanner was used with samples deposited from suspension onto carbon film on 400 mesh copper grids. The SEM measurements were carried out using a Hitachi SU8230 ultrahigh resolution scanning electron microscope and the samples were sputter-coated with $5 \mathrm{~nm}$ gold.

\section{Results and Discussion}

3.1. FT-IR and XRD Analysis. The FT-IR spectra (Figure 1) for the gels dried at $40^{\circ} \mathrm{C}$ show the presence of nitrates characterized by an intense band at $1384 \mathrm{~cm}^{-1}$, indicating that the redox reaction was not initiated at this temperature. In contrast, the absence of this band in gels dried at $140^{\circ} \mathrm{C}$ suggests the consumption of nitrates in the redox reaction with formation of the carboxylates [22-24].

The FT-IR spectra of gels dried at both 40 and $140^{\circ} \mathrm{C}$ show the characteristic bands for the silica matrix: the vibration of $\mathrm{Si}-\mathrm{O}$ bond at $480 \mathrm{~cm}^{-1}$, the vibration of $\mathrm{SiO}_{4}$ tetrahedra at $800 \mathrm{~cm}^{-1}$, and the stretching vibration of Si-O-Si bonds at $1063 \mathrm{~cm}^{-1}[11,25-27]$. The broad band at $3400-3500 \mathrm{~cm}^{-1}$ was assigned to the vibration of $\mathrm{OH}$ groups in water and silica matrix. The vibration bands of bonded $\mathrm{Si}-\mathrm{OH}$ expected at $3200-3400 \mathrm{~cm}^{-1}$ overlap the broad band of water. In the range of $2900-3000 \mathrm{~cm}^{-1}$, the characteristic bands for C-H bonds of the methylene groups $\left(\mathrm{CH}_{2}\right)$ were observed [2830]. In all FT-IR spectra, a characteristic band for $\mathrm{M}-\mathrm{O}$ $(\mathrm{M}=\mathrm{Fe}, \mathrm{Co})$ vibrations appears at $446 \mathrm{~cm}^{-1}$. Moreover, the $\mathrm{M}-\mathrm{OH}$ groups on the surface of the ferrite particles are replaced by $\mathrm{M}-\mathrm{O}-\mathrm{SiO}_{3}$ [31]. In case of gels dried at $40^{\circ} \mathrm{C}$, the sharp bands at $1650 \mathrm{~cm}^{-1}$ are attributable to the deformation vibration of the $\mathrm{H}-\mathrm{O}-\mathrm{H}$ bond, which indicates the presence of water incorporated in the silica matrix $[28,29]$. By increasing the temperature to $140^{\circ} \mathrm{C}$, the characteristic bands for the carboxylate type ligands at $1617 \mathrm{~cm}^{-1}$ and $1360 \mathrm{~cm}^{-1}$ attributed to asymmetric and symmetric vibration of the $\mathrm{COO}^{-}$groups increase, while characteristic bands for the nitrate decrease in intensity. These results are confirmed by the thermal analysis that indicated the decomposition of nitrates at $80-140^{\circ} \mathrm{C}$. The small peak at $1069 \mathrm{~cm}^{-1}$ was assigned to the $\mathrm{C}-\mathrm{O}$ stretching, while those from $1000-700 \mathrm{~cm}^{-1}$ were assigned to the $\mathrm{C}-\mathrm{OH}$ group trapped in the matrix [31]. In case of gels dried at $140^{\circ} \mathrm{C}$, the intensity of the bands decreases from oxalate to succinate, probably due to the removal of the two carboxylate groups. The characteristic bands of carboxylates may overlap the bands of the silica matrix [22]. 

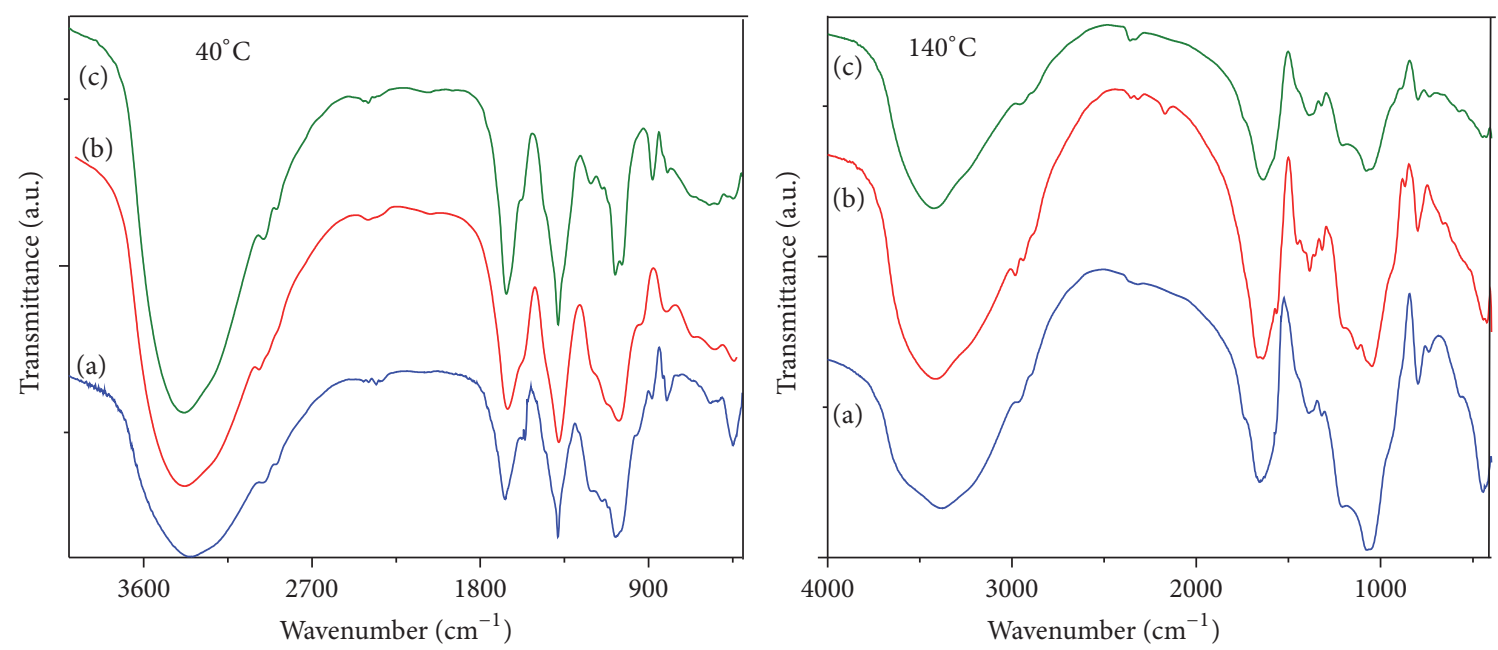

FIGURE 1: FT-IR spectra of the gels obtained using 1,2-ED (a), 1,3-PD (b), and 1,4-BD (c) dried at $40^{\circ} \mathrm{C}$ and $140^{\circ} \mathrm{C}$.

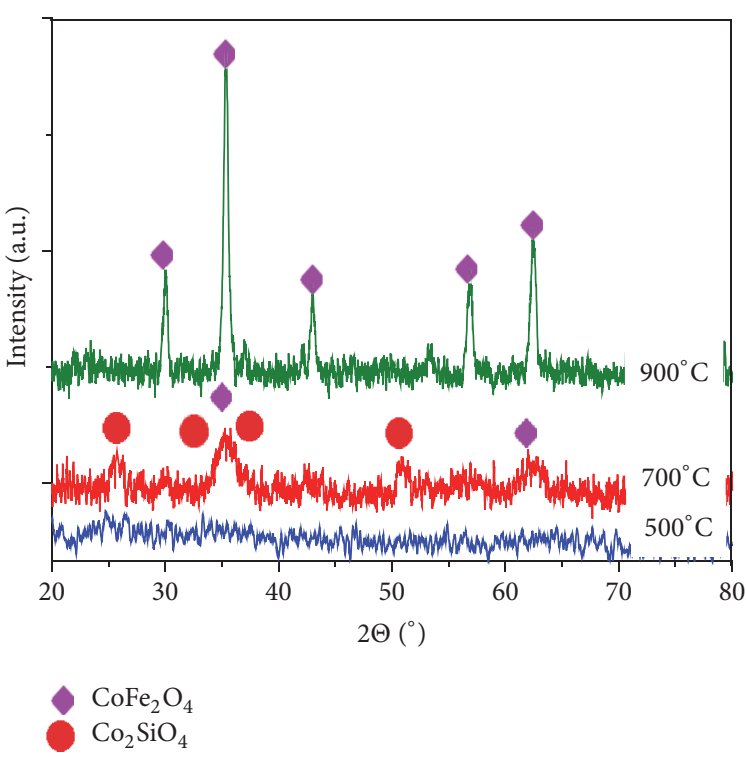

(a)

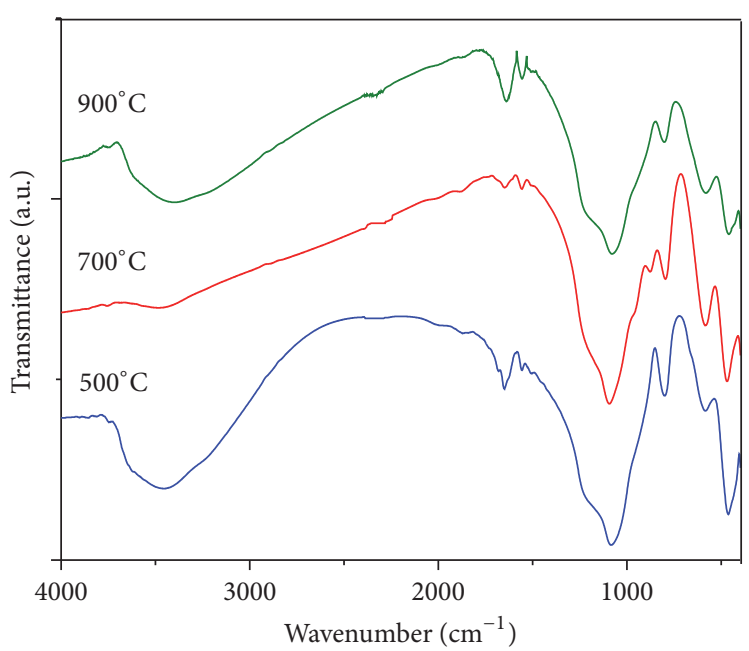

(b)

FIgURE 2: XRD patterns (a) and FT-IR spectra (b) of the gels obtained using 1,2-ED, annealed at 500, 700, and $900^{\circ} \mathrm{C}$.

Figures 2-4 present the XRD patterns (a) and FT-IR spectra (b) of the gels obtained using 1,2-ED, 1,3-PD, and $1,4-\mathrm{BD}$, respectively, annealed at 500,700 , and $900^{\circ} \mathrm{C}$. The diffraction pattern of gels obtained using 1,2-ED (Figure 2(a)) annealed at $500^{\circ} \mathrm{C}$ did not show the presence of crystalline phase, while the FT-IR spectrum (Figure 2(b)) showed both the characteristic bands for the silica matrix ( $\mathrm{Si}-\mathrm{O}$ bonds vibration at $480 \mathrm{~cm}^{-1} ; \mathrm{SiO}_{4}$ tetrahedron vibration at $798 \mathrm{~cm}^{-1}$ and $\mathrm{Si}-\mathrm{O}-\mathrm{Si}$ bonds stretching vibration at $1080 \mathrm{~cm}^{-1} ; \mathrm{H}-\mathrm{OH}$ bond deformation vibration at $1650 \mathrm{~cm}^{-1}$; vibration of $\mathrm{OH}$ groups in water and silica matrix at $3400-3500 \mathrm{~cm}^{-1}$ ) and the characteristic bands for the $\mathrm{M}-\mathrm{O}$ bond at $400-500 \mathrm{~cm}^{-1}$
$[11,25,26,31]$ which indicates the formation of cobalt ferrite, insufficiently crystallized to be noticed in the XRD pattern. At $700^{\circ} \mathrm{C}$, the XRD patterns show the formation of poorly crystallized cobalt ferrite (JCPDS File number 42-1467) contaminated with olivine type cobalt silicate $\left(\mathrm{Co}_{2} \mathrm{SiO}_{4}\right)$ (JCPDS File number 87-0053). The formation of olivine at $700^{\circ} \mathrm{C}$ could be explained by the experimental set-up that inhibits the formation of $\mathrm{Co}_{3} \mathrm{O}_{4}$ spinel oxide up to $900^{\circ} \mathrm{C}$ and favors the formation of $\mathrm{CoO}$ at lower temperatures. The formed $\mathrm{CoO}$ reacts with the amorphous $\mathrm{SiO}_{2}$ during annealing and forms olivine [22]. The FT-IR spectrum of the gel annealed at $700^{\circ} \mathrm{C}$ shows, in addition to the characteristic 


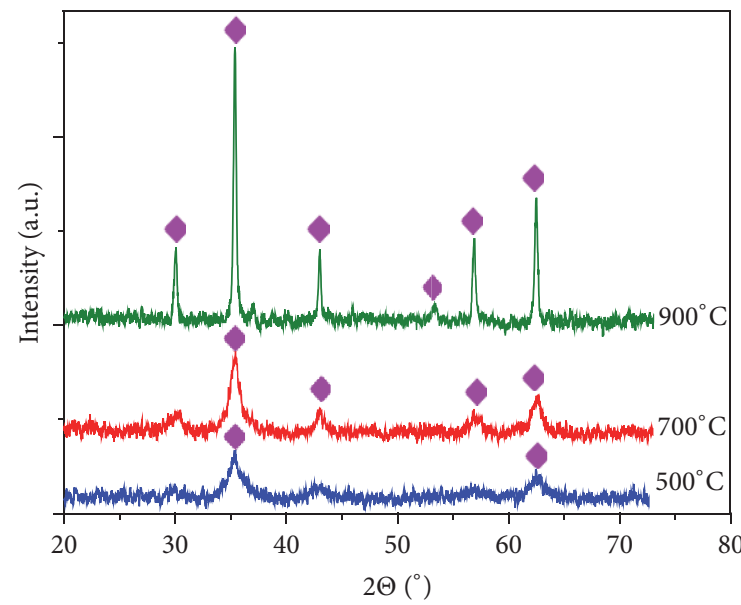

$\mathrm{CoFe}_{2} \mathrm{O}_{4}$

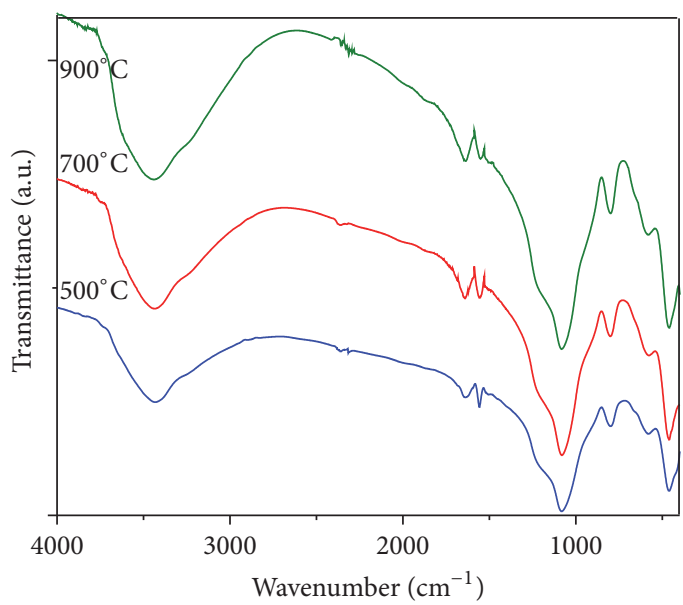

(b)

FIGURE 3: XRD patterns (a) and FT-IR spectra (b) of the gels obtained using 1,3-PD, annealed at 500, 700, and $900^{\circ} \mathrm{C}$.

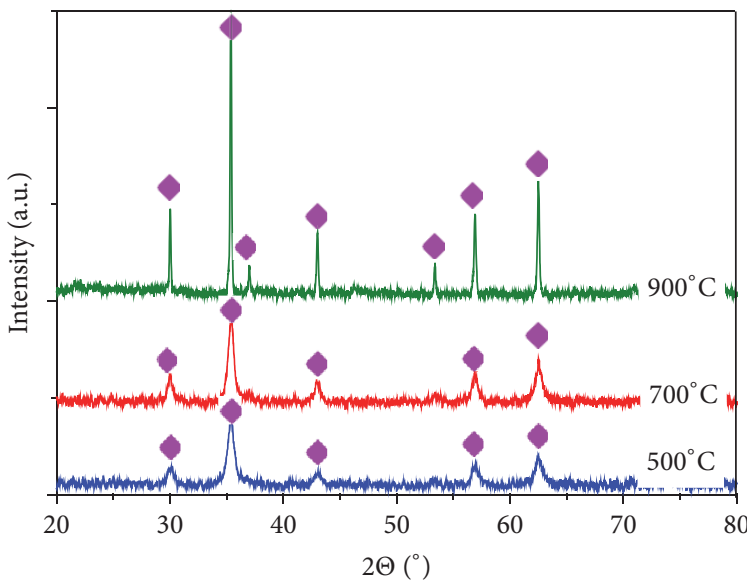

$\mathrm{CoFe}_{2} \mathrm{O}_{4}$

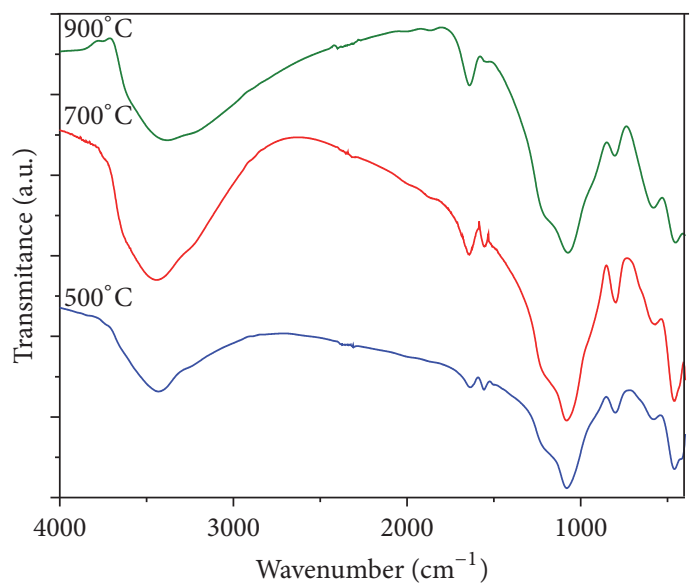

(b)

Figure 4: XRD patterns (a) and FT-IR spectra (b) of the gels obtained using 1,4-BD, annealed at 500, 700, and $900^{\circ} \mathrm{C}$.

bands of the silica matrix, the characteristic bands for cobalt silicate $\left(571\right.$ and $\left.870 \mathrm{~cm}^{-1}\right)[25,26,32,33]$. The formation of well crystallized single phase $\mathrm{CoFe}_{2} \mathrm{O}_{4}$ spinel in the silica matrix occurs at $900^{\circ} \mathrm{C}$. This can be explained by the fact that the reaction between $\mathrm{CoO}$ (formed from $\mathrm{Co}_{3} \mathrm{O}_{4}$ ) and $\mathrm{Fe}_{2} \mathrm{O}_{3}$ is more thermodynamically favored than the reaction between $\mathrm{CoO}$ and $\mathrm{SiO}_{2}$ [22]. The FT-IR spectrum shows the characteristic bands for $\mathrm{CoFe}_{2} \mathrm{O}_{4}\left(466\right.$ and $\left.594 \mathrm{~cm}^{-1}\right)$ and the bands of silica matrix, which are more intense than in the previous cases.

The XRD patterns of the gels obtained using 1,3-PD (Figure 3(a)) show the development of crystalline $\mathrm{CoFe}_{2} \mathrm{O}_{4}$
(JCPDS File number 42-1467). By annealing at $500^{\circ} \mathrm{C}$, poorly crystallized $\mathrm{CoFe}_{2} \mathrm{O}_{4}$ is formed. By increasing the annealing temperature to 700 and $900^{\circ} \mathrm{C}$, the degree of crystallization increases. At $700^{\circ} \mathrm{C}$, the cobalt ferrite formation is more thermodynamically favored than the formation of olivine. The FT-IR spectra (Figure 3(b)) show characteristic bands for $\mathrm{CoFe}_{2} \mathrm{O}_{4}\left(466\right.$ and $\left.594 \mathrm{~cm}^{-1}\right)$ and silica matrix $(480,798$, 1080,1650 , and $\left.3400-3500 \mathrm{~cm}^{-1}\right)[25,26,31,32]$.

At all annealing temperatures, the XRD pattern of gels obtained from 1,4-BD (Figure 4(a)) shows the formation of crystalline $\mathrm{CoFe}_{2} \mathrm{O}_{4}$ as a single phase (JCPDS File number 42-1467). Compared to synthesis using other diols, the 


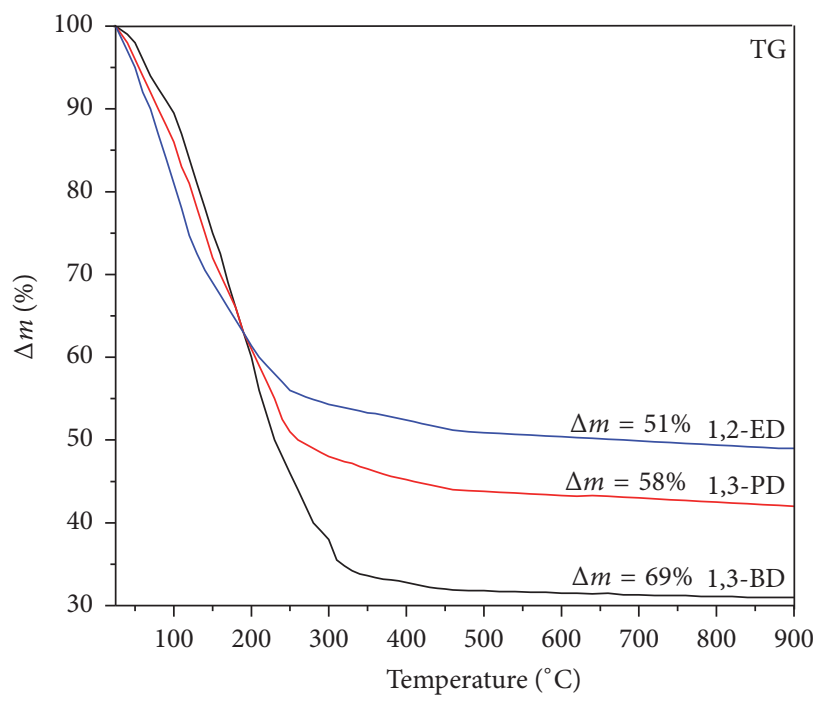

(a)

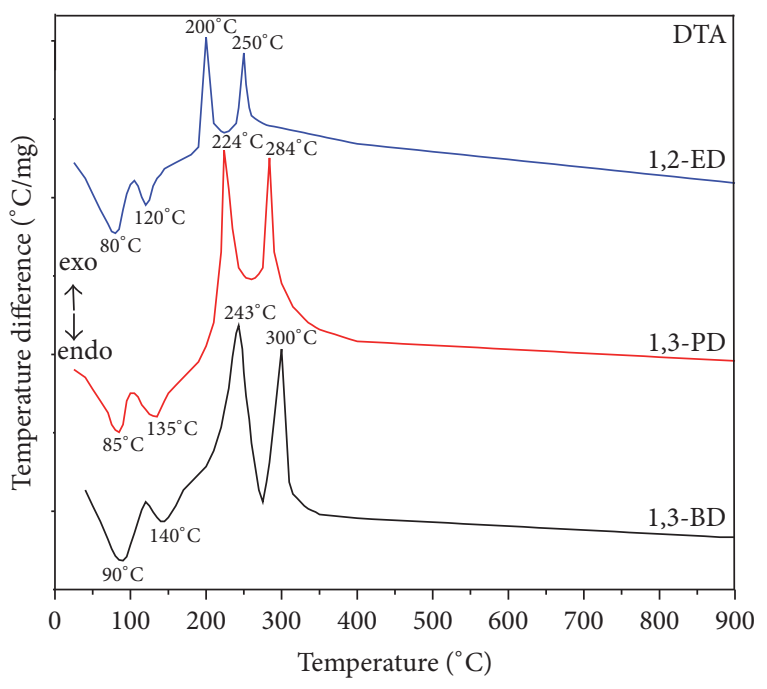

(b)

FIGURE 5: Thermal analysis (TG and DTA) of carboxylate precursors.

TABle 1: Average diameters of $\mathrm{CoFe}_{2} \mathrm{O}_{4}$ crystallites calculated according to the Scherrer equation.

\begin{tabular}{lccc}
\hline Temperature $\left({ }^{\circ} \mathrm{C}\right)$ & \multicolumn{3}{c}{ Average size $(\mathrm{nm})$} \\
& $1,2-\mathrm{ED}$ & $1,3-\mathrm{PD}$ & $1,4-\mathrm{BD}$ \\
\hline 500 & - & 2 & 5 \\
700 & 3 & 5 & 11 \\
900 & 11 & 15 & 22 \\
\hline
\end{tabular}

synthesis method using $1,4-\mathrm{BD}$ is very attractive, since it allows the obtaining of $\mathrm{CoFe}_{2} \mathrm{O}_{4}$ spinel at low temperature. In the FT-IR spectra (Figure 4(b)), the specific bands for $\mathrm{CoFe}_{2} \mathrm{O}_{4}$ (466 and $594 \mathrm{~cm}^{-1}$ ) and silica matrix $(480,798$, 1080,1650 , and $3400-3500 \mathrm{~cm}^{-1}$ ) are present $[11,25,26,32]$.

Based on the XRD patterns and FT-IR spectra it can be concluded that the longer chain length of the carboxylate embedded in the silica matrix favors the formation of crystallized ferrite cobalt single phase at low temperatures. The average size of $\mathrm{CoFe}_{2} \mathrm{O}_{4}$ crystallites was estimated based on the XRD data, using the following Scherrer equation [34]:

$$
D=\frac{0.9 \lambda}{\beta \cos \theta},
$$

where $D$ is the average crystallite size, $\lambda$ is the $\mathrm{X}$-ray wavelength, $\beta$ is the broadening of full width at half maximum (FWHM) intensity of the main intense peak, and $\theta$ is Bragg angle.

The average crystallite size (Table 1 ) indicates that the cobalt ferrite was obtained as nanoparticles. The nanocrystallites sizes increase with the number of methylene groups.

3.2. Thermal Analysis. The formation and decomposition of carboxylate precursors were investigated by the thermal analysis of gels dried at $40^{\circ} \mathrm{C}$.
On TG diagram (Figure 5), the weight losses were $51 \%$ for $1,2-\mathrm{ED}, 58 \%$ for $1,3-\mathrm{PD}$, and $69 \%$ for $1,4-\mathrm{BD}$, respectively, increasing with the increase of the carboxylate precursor chain length, as a consequence of the additional loss of a methylene or ethylene group in the case of malonic and succinic precursors. After $300^{\circ} \mathrm{C}$, the mass slowly decreases up to $900^{\circ} \mathrm{C}$ due to the dehydroxylation of the silica matrix. In all cases, the DTA diagram (Figure 5) shows (i) two endothermic effects corresponding to the redox reaction between nitrates and diol with the formation of carboxylate anions that coordinate to the metallic ions and (ii) two exothermic effects corresponding to the oxidative decomposition of the precursor (oxalate, malonate, and succinate) and the combustion of organic chains intercalated in the silica network. The two exothermic effects at $80-140^{\circ} \mathrm{C}$ suggest that $\mathrm{Fe}(\mathrm{III})$ and $\mathrm{Co}(\mathrm{II})$ nitrates react separately with the diol due to the difference of the aqua cations acidity: $\mathrm{pK}_{\mathrm{a}\left[\mathrm{Fe}\left(\mathrm{NO}_{3}\right)_{3}\right]}=$ 2.22 and $\mathrm{pK}_{\mathrm{a}\left[\mathrm{Co}\left(\mathrm{NO}_{3}\right)_{2}\right]}=12.2[22,23]$. Thermal behavior of the metal nitrates, diol solutions, suggests the formation of a homogeneous mixture of homonuclear $\mathrm{Fe}$ (III) and $\mathrm{Co}$ (II) carboxylates. The two endothermic effects at $200-300^{\circ} \mathrm{C}$ on DTA curves of gels show that the decomposition of precursors takes place in two stages indicating that both Fe(III) and Co(II) carboxylic compounds are formed separately. Thus, the first exothermic effect corresponds to decomposition of cobalt oxalates $\left(200^{\circ} \mathrm{C}\right)$, malonates $\left(224^{\circ} \mathrm{C}\right)$, and succinates $\left(243^{\circ} \mathrm{C}\right)$, while the second exothermic effect corresponds to the decomposition of iron oxalates $\left(250^{\circ} \mathrm{C}\right)$, malonates $\left(284^{\circ} \mathrm{C}\right)$, and succinates $\left(300^{\circ} \mathrm{C}\right)$. The decomposition of gel obtained from 1,4-BD occurs at the highest temperatures, indicating that, by increasing the number of methylene groups, the thermic effect increases and shifts toward higher temperatures. 
TABLE 2: Thermodynamic parameters of the compounds formed during synthesis.

\begin{tabular}{lccccc}
\hline Compound $\Delta H^{o}(\mathrm{kcal} / \mathrm{mol})$ & $S^{o}(\mathrm{cal} / \mathrm{mol} \mathrm{K})$ & \multicolumn{4}{c}{$c_{p}{ }^{o}$} \\
& & & $a$ & $b \cdot 10^{3}$ & $c \cdot 10^{-5}$ \\
\hline $\mathrm{CoO}$ & -56923 & 12.7 & 10.8 & 2.6 & 14.4 \\
$\mathrm{Fe}_{2} \mathrm{O}_{3}$ & -63200 & 14.1 & 12.6 & 8.5 & -0.8 \\
$\mathrm{SiO}_{2}$ & -205 & 10.1 & 11.2 & 8.2 & -2.7 \\
$\mathrm{CoFe}_{2} \mathrm{O}_{4}$ & -341548 & 30.1 & 39.9 & 4.2 & 3.3 \\
$\mathrm{Co}_{2} \mathrm{SiO}_{4}$ & -346170 & 38.2 & 41.1 & 4.4 & -3.6 \\
\hline
\end{tabular}

3.3. Thermodynamic Parameters. In order to determine the stability of cobalt ferrite and cobalt silicate, the variation of the standard enthalpy of formation $\left(\Delta H^{o}\right)$, entropy $\left(S^{o}\right)$, and molar heat capacity $\left(c_{p}{ }^{o}\right)$ and the decomposition temperature $\left(T_{D}\right)$ were calculated. For calculations, room temperature $\left(T_{o}\right.$ $=25^{\circ} \mathrm{C}$ ) was considered as reference. The thermodynamic data of various reactants and products is presented in the literature [35]. The thermodynamic parameters of the compounds formed during synthesis are listed in Table 2. $c_{p}$ was calculated according to the following equation $[35,36]$ :

$$
c_{p}^{o}=a+b T+c T^{2}
$$

where $a, b$, and $c$ are the molar heat capacity coefficients characteristics of each substance and $T$ is the temperature.

The standard enthalpy of formation at temperature $T\left(\Delta H_{T}{ }^{o}\right)$ was calculated using the values of standard enthalpy of formation at $25^{\circ} \mathrm{C}\left(\Delta H_{o}{ }^{o}\right)(\mathrm{CoO}=-60.5 \mathrm{kcal} / \mathrm{mol}$, $\mathrm{Fe}_{2} \mathrm{O}_{3}=-44.4 \mathrm{kcal} / \mathrm{mol}, \mathrm{SiO}_{2}=-36.8 \mathrm{kcal} / \mathrm{mol}, \mathrm{CoFe}_{2} \mathrm{O}_{4}=$ $-541.7 \mathrm{kcal} / \mathrm{mol}$, and $\mathrm{Co}_{2} \mathrm{SiO}_{4}=-55.2 \mathrm{kcal} / \mathrm{mol}$ ) according to the following equation $[35,36]$ :

$$
\Delta H_{T}^{o}=\Delta H_{o}^{o}+c_{p}^{o} \cdot(T-25) .
$$

Using the values of the entropy at $25^{\circ} \mathrm{C}\left(S_{o}{ }^{o}\right)(\mathrm{CoO}$ $=-53,5 \mathrm{cal} / \mathrm{mol} \cdot \mathrm{K}, \quad \mathrm{Fe}_{2} \mathrm{O}_{3}=-2588 \mathrm{cal} / \mathrm{mol} \mathrm{K}, \quad \mathrm{SiO}_{2}=$ $-2497 \mathrm{cal} / \mathrm{mol} \mathrm{K}, \mathrm{CoFe}_{2} \mathrm{O}_{4}=-1461 \mathrm{cal} / \mathrm{mol} \mathrm{K}, \mathrm{Co}_{2} \mathrm{SiO}_{4}=$ $-1495 \mathrm{cal} / \mathrm{mol} \mathrm{K})$, the entropy at temperature $T\left(S_{T}{ }^{o}\right)$ was calculated according to the following equation [36]:

$$
S_{T}^{o}=S_{o}^{o}+\int_{25}^{T} c_{p}^{o} \frac{d T}{T},
$$

where $S_{o}^{o}$ is the standard entropy at $T=25^{\circ} \mathrm{C}$ and $c_{p}^{o}$ is the molar heat capacity.

The variation of Gibbs free energy $\left(\Delta G_{T}{ }^{o}\right)$ in function of the temperature in standard condition was calculated according to the following equation [36]:

$$
\Delta G_{T}^{o}=\Delta H_{T}^{o}-T * S_{T}^{o},
$$

where $\Delta G_{T}{ }^{o}$ is the variation of Gibbs free energy, $\Delta H^{o}$ is the enthalpy variation at temperature $T, T$ is the temperature, and $\Delta S_{T}{ }^{o}$ is the entropy at temperature $T$.

Table 3 presents the thermodynamic parameters calculated for $\mathrm{CoO}, \mathrm{Fe}_{2} \mathrm{O}_{3}$, and $\mathrm{SiO}_{2}$, while Table 4 presents the thermodynamic data calculated for olivine and cobalt ferrite.
Considering that the equilibrium between different reaction products $\mathrm{CoFe}_{2} \mathrm{O}_{4}$ and $\mathrm{Co}_{2} \mathrm{SiO}_{4}$ and their precursors $\left(\mathrm{CoO}, \mathrm{Fe}_{2} \mathrm{O}_{3}\right.$, and $\left.\mathrm{SiO}_{2}\right)$ is influenced by the value of the thermodynamic parameters, the variation of these parameters was calculated. The decomposition of cobalt ferrite takes place according to (7).

$$
\mathrm{CoFe}_{2} \mathrm{O}_{4} \longrightarrow \mathrm{CoO}+\mathrm{Fe}_{2} \mathrm{O}_{3}
$$

The calculations were performed using the thermal decomposition of oxalates (in case of using 1,2-EG as chelator) which corresponds to the temperature at which the pressure of $\mathrm{CO}_{2}$ is equal to 1 atmosphere.

The thermodynamic data presented in Tables 3 and 4 was used to calculate the reaction enthalpy $\left(\Delta H_{R}\right)$ and reaction entropy $\left(\Delta S_{R}\right)$ for cobalt ferrite decomposition according to (8) and (9):

$$
\Delta H_{R}=\sum n_{\text {prod }} \cdot \Delta H_{\text {prod }}^{0}-\sum n_{\text {react }} \cdot \Delta H_{\text {react }}^{0},
$$

where $n_{\text {prod }}$ and $n_{\text {react }}$ are the stoichiometric coefficients of reaction products and reactants, respectively, and $\Delta H_{\text {prod }}^{0}$ and $\Delta H_{\text {react }}^{0}$ are the variations of enthalpy of reaction products and reactants, respectively.

$$
\begin{aligned}
\Delta S_{R}= & S_{o}^{o}+\int_{25}^{T} n_{\text {prod }} \cdot c_{p, \text { prod }}^{o} \frac{d T}{T}-\int_{25}^{T} n_{\text {react }} \\
& \cdot c_{p, \text { react }}^{o} \frac{d T}{T},
\end{aligned}
$$

where $S_{o}^{o}$ is the standard entropy at $T=25^{\circ} \mathrm{C}, n_{\text {prod }}$ and $n_{\text {react }}$ are the stoichiometric coefficients of reaction products and reactants, and $c_{p \text {,prod }}^{o}$ and $c_{p \text {,react }}^{o}$ are the molar heat capacities of reaction products and reactants, respectively.

The variation of Gibbs free energy of the reaction $\left(\Delta G_{R}\right)$ was calculated according to (6) using calculated $\Delta H_{R}$ and $\Delta S_{R}$. In the case of cobalt ferrite decomposition, the reaction enthalpy and entropy increase with the increase of temperature and decrease with the decrease of free enthalpy (Figure 6). There is a temperature range where $\Delta G_{R}=0$ and $\Delta G_{R}$ can be calculated by interpolation using the function $\Delta G_{R}=f(T)$. The decomposition temperature is considered the temperature where $\Delta H_{R}=0$.

Table 5 shows the thermodynamic parameters at decomposition temperature $\left(T_{D}=348^{\circ} \mathrm{C}\right)$ for cobalt ferrite. The necessary enthalpy to reach the decomposition temperature is $642 \mathrm{kcal} / \mathrm{mol}$. The decomposition temperature is reached when the lattice energy of the reaction products is equal to the lattice energy of cobalt ferrite. If the lattice energy of cobalt ferrite is lower, it tends to pass into a more stable form. In our case, the lattice energy of cobalt ferrite is lower than that of the two reaction products. 
TABLE 3: Thermodynamic parameters at different temperatures for $\mathrm{CoO}, \mathrm{SiO}_{2}$, and $\mathrm{Fe}_{2} \mathrm{O}_{3}$.

\begin{tabular}{lcccccccccccc}
\hline \multirow{2}{*}{$T\left({ }^{\circ} \mathrm{C}\right)$} & \multicolumn{3}{c}{$c_{p}{ }^{o}(\mathrm{cal} / \mathrm{mol} \cdot \mathrm{K})$} & \multicolumn{3}{c}{$\Delta H^{o}(\mathrm{kcal} / \mathrm{mol})$} & \multicolumn{3}{c}{$S^{o}\left(\mathrm{cal} / \mathrm{mol}^{\prime} \mathrm{K}\right)$} & \multicolumn{3}{c}{$\Delta G^{o}\left(\mathrm{kcal} / \mathrm{mol}^{2}\right.$} \\
& $\mathrm{CoO}$ & $\mathrm{Fe}_{2} \mathrm{O}_{3}$ & $\mathrm{SiO}_{2}$ & $\mathrm{CoO}$ & $\mathrm{Fe}_{2} \mathrm{O}_{3}$ & $\mathrm{SiO}_{2}$ & $\mathrm{CoO}$ & $\mathrm{Fe}_{2} \mathrm{O}_{3}$ & $\mathrm{SiO}_{2}$ & $\mathrm{CoO}^{2}$ & $\mathrm{Fe}_{2} \mathrm{O}_{3}$ & $\mathrm{SiO}_{2}$ \\
\hline 25 & 12.6 & 2560 & 2471 & -57.1 & -58.1 & 4.7 & 12.7 & 31.1 & 26.5 & -60.9 & -67.4 & -3.2 \\
100 & 12.6 & 3409 & 3291 & -55.8 & 240 & 293 & 16.4 & 884 & 850 & -62.4 & -113 & -47.1 \\
200 & 12.7 & 4258 & 4111 & -54.6 & 624 & 663 & 19.4 & 1736 & 1672 & -64.1 & -244 & -173 \\
300 & 12.9 & 5107 & 4931 & -53.3 & 1092 & 115 & 21.5 & 2587 & 2494 & -66.2 & -460 & -381 \\
400 & 13.0 & 5956 & 5751 & -52.0 & 1645 & 1649 & 23.5 & 3438 & 3316 & -68.4 & -761 & -672 \\
500 & 13.2 & 6805 & 6571 & -50.7 & 2283 & 2265 & 25.3 & 4288 & 4137 & -70.9 & -1148 & -1045 \\
600 & 13.4 & 7654 & 7391 & -49.3 & 3006 & 2963 & 26.8 & 5139 & 4959 & -73.5 & -1619 & -1499 \\
700 & 13.6 & 8503 & 8211 & -48.0 & 3814 & 3744 & 28.3 & 5989 & 5780 & -76.2 & -2176 & -2036 \\
800 & 13.8 & 9352 & 9031 & -46.6 & 4706 & 4606 & 29.6 & 6839 & 6601 & -79.1 & -2817 & -2655 \\
900 & 14.0 & 10201 & 9851 & -45.2 & 5684 & 5550 & 30.8 & 7690 & 7422 & -82.2 & -3543 & -3357 \\
\hline
\end{tabular}

TABLE 4: Thermodynamic parameters at different temperatures for $\mathrm{CoFe}_{2} \mathrm{O}_{4}$ and $\mathrm{Co}_{2} \mathrm{SiO}_{4}$.

\begin{tabular}{lcccccccc}
\hline \multirow{2}{*}{$\left({ }^{\circ} \mathrm{C}\right)$} & \multicolumn{2}{c}{$c_{p}{ }^{o}(\mathrm{cal} / \mathrm{mol} \cdot \mathrm{K})$} & \multicolumn{2}{c}{$\Delta H^{o}(\mathrm{kcal} / \mathrm{mol})$} & \multicolumn{2}{c}{$S^{o}(\mathrm{cal} / \mathrm{mol} \cdot \mathrm{K})$} & \multicolumn{2}{c}{$\Delta G^{o}(\mathrm{kcal} / \mathrm{mol})$} \\
& $\mathrm{CoFe}_{2} \mathrm{O}_{4}$ & $\mathrm{Co}_{2} \mathrm{SiO}_{4}$ & $\mathrm{CoFe}_{2} \mathrm{O}_{4}$ & $\mathrm{Co}_{2} \mathrm{SiO}_{4}$ & $\mathrm{CoFe}_{2} \mathrm{O}_{4}$ & $\mathrm{Co}_{2} \mathrm{SiO}_{4}$ & $\mathrm{CoFe}_{2} \mathrm{O}_{4}$ & $\mathrm{Co}_{2} \mathrm{SiO}_{4}$ \\
\hline 25 & 1312 & 1348 & -339 & -343 & 38.8 & 47.2 & -351 & -358 \\
100 & 1736 & 1785 & -187 & -187 & 474 & 495 & -376 & -385 \\
200 & 2151 & 2221 & 8.24 & 13.5 & 907 & 940 & -445 & -457 \\
300 & 2584 & 2657 & 245 & 257 & 1339 & 1384 & -558 & -573 \\
400 & 3008 & 3093 & 525 & 545 & 1769 & 1826 & -713 & -733 \\
500 & 3432 & 3529 & 847 & 876 & 2198 & 2268 & -911 & -938 \\
600 & 3856 & 3965 & 1211 & 1251 & 2627 & 2708 & -1153 & -1187 \\
700 & 4280 & 4401 & 1618 & 1669 & 3055 & 3149 & -1437 & -1480 \\
800 & 4704 & 4837 & 2067 & 2131 & 3483 & 3589 & -1764 & -1816 \\
900 & 5128 & 5273 & 2559 & 2636 & 3910 & 4028 & -2133 \\
\hline
\end{tabular}

TABLE 5: Thermodynamic parameters for cobalt ferrite decomposition at the decomposition temperature.

\begin{tabular}{lcccc}
\hline Compound & $c_{p}{ }^{o}(\mathrm{cal} / \mathrm{mol} \cdot \mathrm{K})$ & $\Delta H^{o}(\mathrm{kcal} / \mathrm{mol})$ & $S^{o}(\mathrm{cal} / \mathrm{mol} \cdot \mathrm{K})$ & $\Delta G^{o}(\mathrm{kcal} / \mathrm{mol})$ \\
\hline $\mathrm{CoFe}_{2} \mathrm{O}_{4}$ & 2673 & 301 & 1429 & -587 \\
$\mathrm{CoO}$ & 12.9 & -53.0 & 21.9 & -66.6 \\
$\mathrm{Fe}_{2} \mathrm{O}_{3}$ & 5285 & 1201 & 2766 & -517 \\
\hline$T_{D}$ & 2625 & 847 & 1359 & 3.5 \\
\hline
\end{tabular}

TABLE 6: Thermodynamic parameters for olivine decomposition at the decomposition temperature.

\begin{tabular}{lcccc}
\hline Compound & $c_{p}{ }^{o}(\mathrm{cal} / \mathrm{mol} \cdot \mathrm{K})$ & $\Delta H^{o}(\mathrm{kcal} / \mathrm{mol})$ & $S^{o}(\mathrm{cal} / \mathrm{mol} \cdot \mathrm{K})$ & $\Delta G^{o}(\mathrm{kcal} / \mathrm{mol})$ \\
\hline $\mathrm{CoFe}_{2} \mathrm{O}_{4}$ & 2848 & 378 & 1577 & -638 \\
$\mathrm{CoO}$ & 12.9 & -52.7 & 22.4 & -67.1 \\
$\mathrm{Fe}_{2} \mathrm{O}_{3}$ & 5290 & 1339 & 2854 & -499 \\
\hline$T_{D}$ & 2468 & 855 & 1321 & 4.7 \\
\hline
\end{tabular}

Similarly, the thermodynamic parameters were calculated for the reaction of olivine decomposition according to (10).

$$
\mathrm{Co}_{2} \mathrm{SiO}_{4} \longrightarrow 2 \mathrm{CoO}+\mathrm{SiO}_{2}
$$

Also, in the case of olivine decomposition, the reaction enthalpy and entropy increase with increase of temperature and decrease with the decrease of free enthalpy (Figure 7). Table 6 shows the thermodynamic parameters at the 


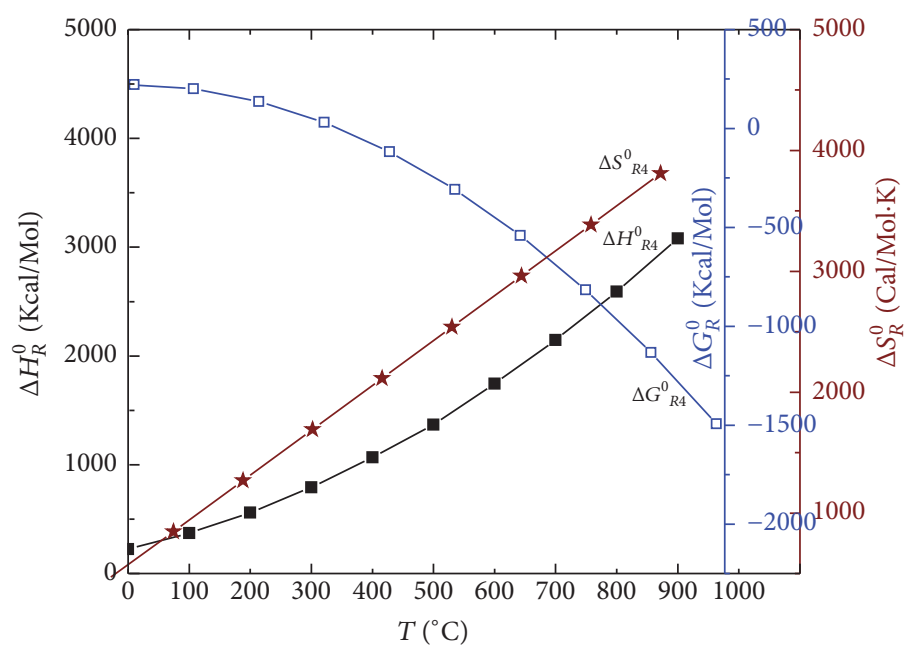

FIGURE 6: Variation of thermodynamic parameters for cobalt ferrite decomposition.

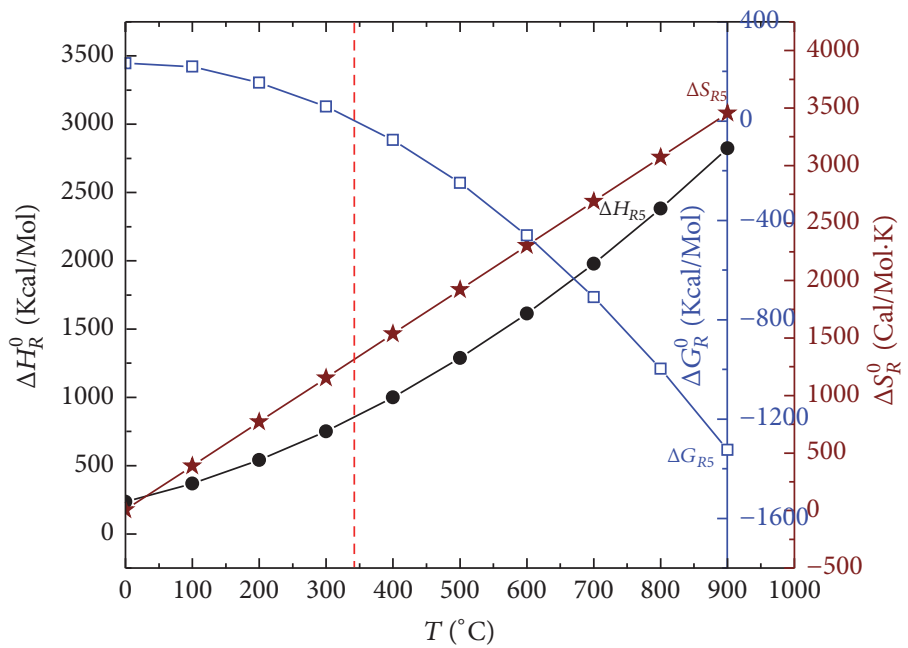

FIGURE 7: Variation of thermodynamic parameters for olivine decomposition.

decomposition temperature for olivine $\left(T_{D}=370.6^{\circ} \mathrm{C}\right)$. The necessary enthalpy to reach the decomposition temperature is $724 \mathrm{kcal} / \mathrm{mol}$.

3.4. SEM and TEM Analysis. Figure 8 shows the SEM images of $\mathrm{CoFe}_{2} \mathrm{O}_{4}$ nanocrystallites embedded in the silica matrix. The SEM images revealed spherical particles assembled in high agglomerations of irregular shape.

Using 1,2-ED and 1,4-BD for the carboxylate precursor obtaining, larger agglomerates were observed. The agglomerates' size increases also with the annealing temperature.

The TEM images (Figure 9) show that the size of the nanoparticle spheres increases with the number of methylene groups of the carboxylate precursor. The size of nanocrystallites obtained from the Scherrer equation was confirmed by the nanoparticle size obtained from TEM images. In the case of gels annealed at $900^{\circ} \mathrm{C}$, nanoparticles of $10 \mathrm{~nm}$ to $23 \mathrm{~nm}$ diameters were obtained.

\section{Conclusions}

The embedding of the reactants in the silica matrix followed by the redox reaction with formation of carboxylate type precursors (oxalate, malonate, and succinate, respectively) and their thermal decomposition allowed the obtaining of $70 \% \mathrm{CoFe}_{2} \mathrm{O}_{4} / 30 \% \mathrm{SiO}_{2}$ (wt $\%$ ) nanocomposites. Longer 


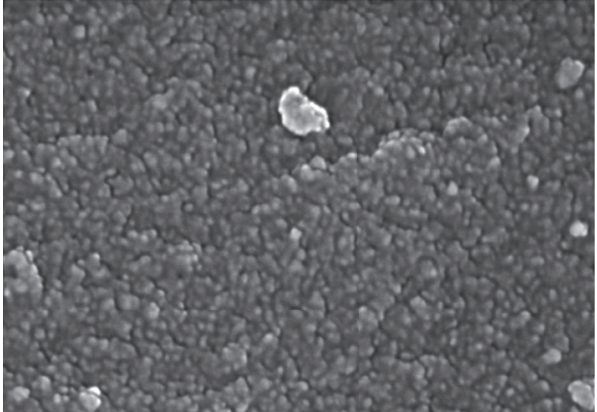

(a)

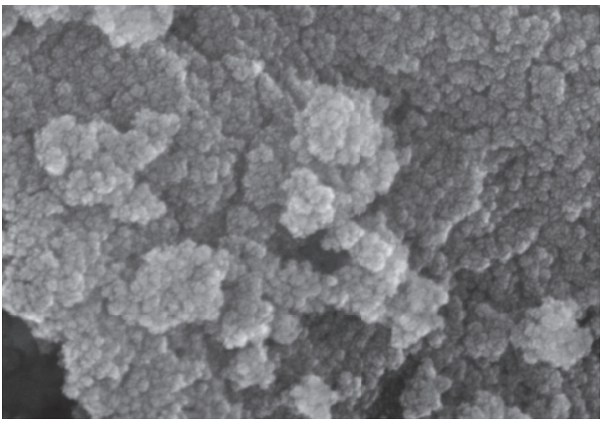

(c)

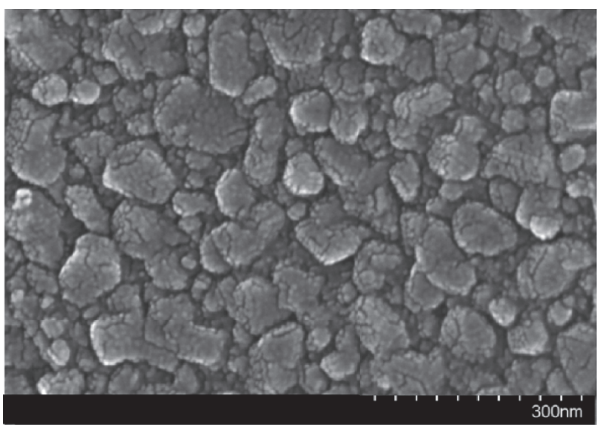

(e)

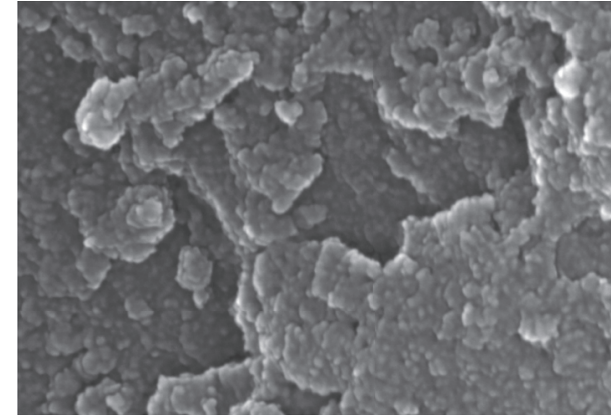

(b)

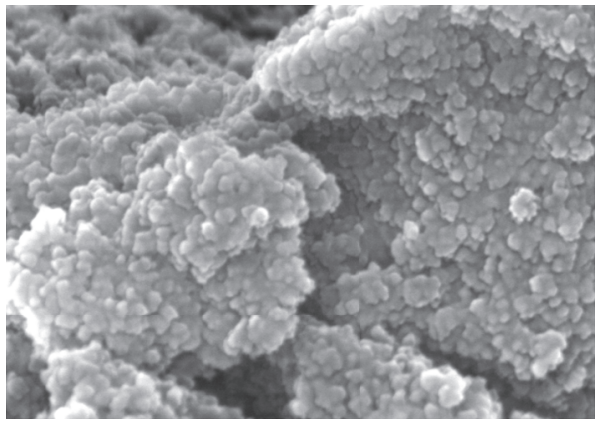

(d)

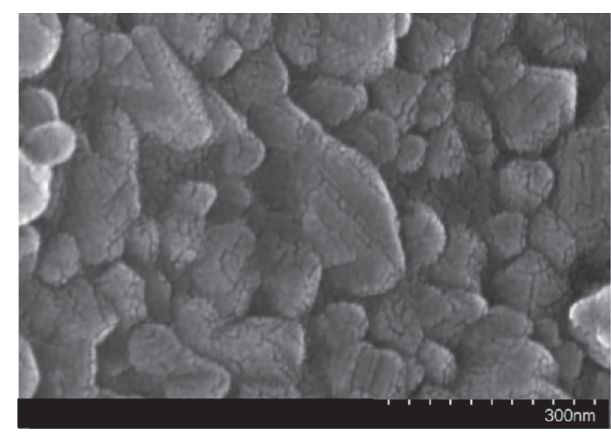

(f)

Figure 8: SEM images of gels obtained using 1,2-ED, 1,3-PD, and 1,4-BD, annealed at 700 and $900^{\circ} \mathrm{C}$.

chain diols resulted in higher weight losses in the decomposition process of the precursors and higher decomposition temperature. Longer chain precursors embedded in the silica matrix favored the formation of single phase cobalt ferrite, at lower temperatures: $\mathrm{Co}$ and $\mathrm{Fe}$ succinates allow the obtaining of crystalline cobalt ferrite at $500^{\circ} \mathrm{C}$, while $\mathrm{Co}$ and $\mathrm{Fe}$ oxalates give amorphous cobalt ferrite at $500^{\circ} \mathrm{C}$, poorly crystalline cobalt ferrite with traces of olivine at $700^{\circ} \mathrm{C}$, and single phase crystalline cobalt ferrite at $900^{\circ} \mathrm{C}$. The average nanocrystallites size of cobalt ferrite ranges from 11 to $22 \mathrm{~nm}$ in case of annealing at $900^{\circ} \mathrm{C}$, while in case of using 1,4$\mathrm{BD}$ the average nanocrystallite size can reach $5 \mathrm{~nm}$ after annealing at $500^{\circ} \mathrm{C}$. The nanocrystallites' size increases with the increase of the methylene groups in the precursors and the annealing temperature. The enthalpy and entropy of the cobalt ferrite and olivine decomposition reaction increase with the increase of annealing temperature. The presented synthesis method offers a viable alternative for obtaining $\mathrm{CoFe}_{2} \mathrm{O}_{4} / \mathrm{SiO}_{2}$ nanocomposites with applications in the field of catalysis and magnetic materials.

\section{Conflicts of Interest}

The authors declare that there are no conflicts of interest regarding the publication of this paper.

\section{Acknowledgments}

The authors are grateful for financial support from the National Authority for Scientific Research and Innovation 


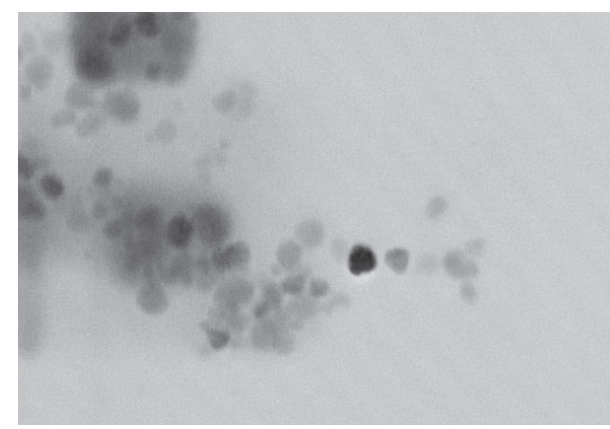

(a)

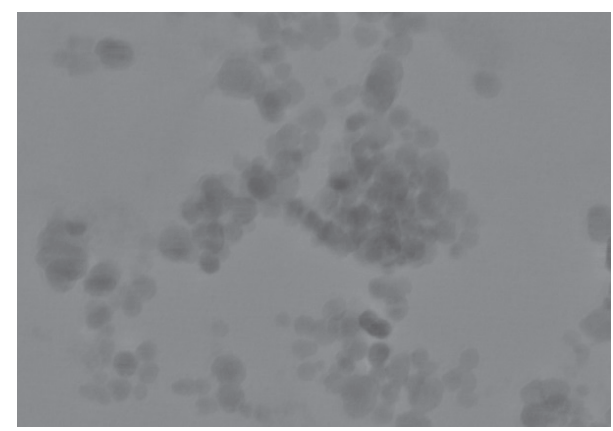

(c)

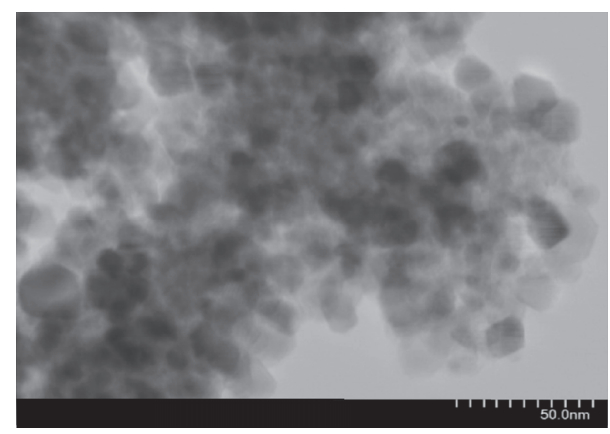

(e)

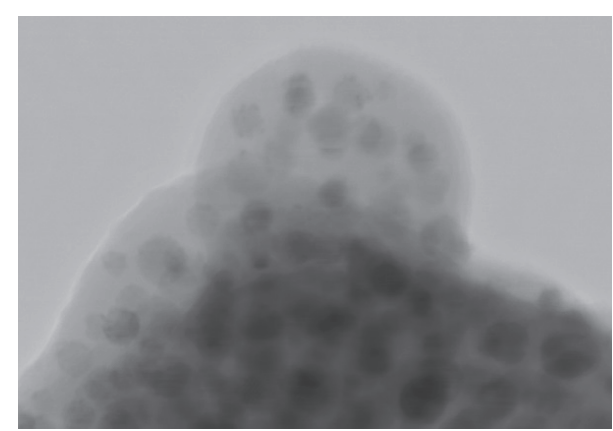

(b)

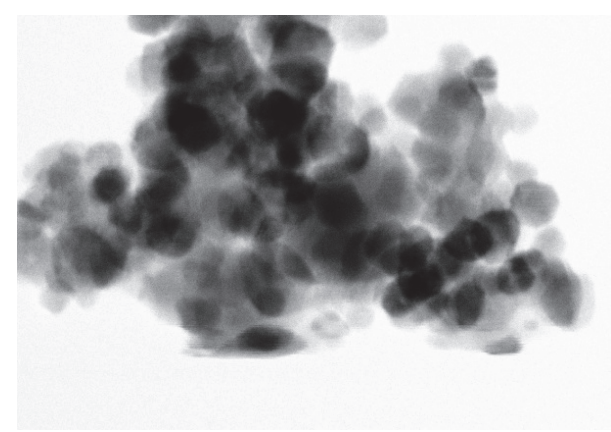

(d)

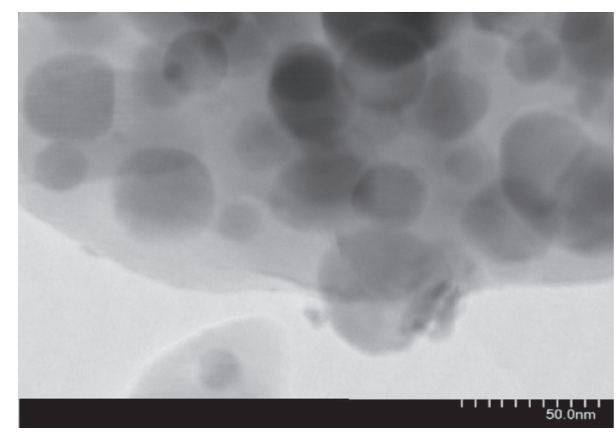

(f)

Figure 9: TEM images of gels obtained using 1,2-ED, 1,3-PD, and 1,4-BD, annealed at 700 and $900^{\circ} \mathrm{C}$.

(ANCSI) Core Program (Project no. 16.40.02.01) and Sectoral Operational Programme "Increase of Economic Competitiveness", Priority Axis II (Project no. 1887, INOVAOPTIMA, code SMIS-CSNR 49164).

\section{References}

[1] P. H. C. Camargo, K. G. Satyanarayana, and F. Wypych, "Nanocomposites: synthesis, structure, properties and new application opportunities," Materials Research, vol. 12, no. 1, pp. 1-39, 2009.

[2] F. Liu, S. Laurent, A. Roch, L. Vander Elst, and R. N. Muller, "Size-controlled synthesis of $\mathrm{CoFe}_{2} \mathrm{O}_{4}$ nanoparticles potential contrast agent for MRI and investigation on their sizedependent magnetic properties," Journal of Nanomaterials, vol. 2013, Article ID 462540, 9 pages, 2013.
[3] H. Jin, Q. Chen, Z. Chen, Y. Hu, and J. Zhang, "MultiLeapMotion sensor based demonstration for robotic refine tabletop object manipulation task," CAAI Transactions on Intelligence Technology, vol. 1, no. 1, pp. 104-113, 2016.

[4] H. Wei, D. Ding, X. Yan et al., “Tungsten trioxide/zinc tungstate bilayers: electrochromic behaviors, energy storage and electron transfer," Electrochimica Acta, vol. 132, pp. 58-66, 2014.

[5] S. W. da Silva, R. C. Pedroza, P. P. C. Sartoratto et al., "Raman spectroscopy of cobalt ferrite nanocomposite in silica matrix prepared by sol-gel method," Journal of Non-Crystalline Solids, vol. 352, no. 9-20, pp. 1602-1606, 2006.

[6] S. Wei, Q. Wang, J. Zhu, L. Sun, H. Lin, and Z. Guo, "Multifunctional composite core-shell nanoparticles," Nanoscale, vol. 3, no. 11, pp. 4474-4502, 2011.

[7] B. G. Toksha, S. E. Shirsath, S. M. Patange, and K. M. Jadhav, "Structural investigations and magnetic properties of cobalt ferrite nanoparticles prepared by sol-gel auto combustion 
method," Solid State Communications, vol. 147, no. 11-12, pp. 479-483, 2008.

[8] T. Ramesh, S. Bharadwaj, and S. R. Murthy, "CoFe $\mathrm{O}_{4}-\mathrm{SiO}_{2}$ composites: preparation and magnetodielectric properties," Journal of Materials, vol. 2016, Article ID 7518468, 7 pages, 2016.

[9] C. H. Chia, S. Zakaria, M. Yusoff et al., "Size and crystallinitydependent magnetic properties of $\mathrm{CoFe}_{2} \mathrm{O}_{4}$ nanocrystals," Ceramics International, vol. 36, no. 2, pp. 605-609, 2010.

[10] X.-M. Liu, S.-Y. Fu, and L.-P. Zhu, "High-yield synthesis and characterization of monodisperse sub-microsized $\mathrm{CoFe}_{2} \mathrm{O}_{4}$ octahedra," Journal of Solid State Chemistry, vol. 180, no. 2, pp. 461-466, 2007.

[11] M. M. El-Okr, M. A. Salem, M. S. Salim, R. M. El-Okr, M. Ashoush, and H. M. Talaat, "Synthesis of cobalt ferrite nano-particles and their magnetic characterization," Journal of Magnetism and Magnetic Materials, vol. 323, no. 7, pp. 920-926, 2011.

[12] M. Houshiar, F. Zebhi, Z. J. Razi, A. Alidoust, and Z. Askari, "Synthesis of cobalt ferrite $\left(\mathrm{CoFe}_{2} \mathrm{O}_{4}\right)$ nanoparticles using combustion, coprecipitation, and precipitation methods: a comparison study of size, structural, and magnetic properties," Journal of Magnetism and Magnetic Materials, vol. 371, pp. 4348, 2014.

[13] L. A. García Cerda and S. M. Montemayor, "Synthesis of $\mathrm{CoFe}_{2} \mathrm{O}_{4}$ nanoparticles embedded in a silica matrix by the citrate precursor technique," Journal of Magnetism and Magnetic Materials, vol. 294, no. 2, pp. e43-e46, 2005.

[14] F. Huixia, C. Baiyi, Z. Deyi, Z. Jianqiang, and T. Lin, "Preparation and characterization of the cobalt ferrite nano-particles by reverse coprecipitation," Journal of Magnetism and Magnetic Materials, vol. 356, pp. 68-72, 2014.

[15] D. Zhao, X. Wu, H. Guan, and E. Han, "Study on supercritical hydrothermal synthesis of $\mathrm{CoFe}_{2} \mathrm{O}_{4}$ nanoparticles," Journal of Supercritical Fluids, vol. 42, no. 2, pp. 226-233, 2007.

[16] Q. Lin, J. Lin, Y. He, R. Wang, and J. Dong, “The structural and magnetic properties of gadolinium doped $\mathrm{CoFe}_{2} \mathrm{O}_{4}$ nanoferrites," Journal of Nanomaterials, vol. 2015, Article ID 294239 , 6 pages, 2015.

[17] S.-P. Rwei, L. Y. Wang, and P.-W. Yang, "Synthesis and magnetorheology study of iron oxide and iron cobalt oxide suspensions," Journal of Nanomaterials, vol. 2013, Article ID 612894, 7 pages, 2013.

[18] D. Gingasu, I. Mindru, L. Patron et al., "Green synthesis methods of $\mathrm{CoFe}_{2} \mathrm{O}_{4}$ and $\mathrm{Ag}-\mathrm{CoFe}_{2} \mathrm{O}_{4}$ nanoparticles using hibiscus extracts and their antimicrobial potential," Journal of Nanomaterials, vol. 2016, Article ID 2106756, 12 pages, 2016.

[19] J. Chen, Y. Wang, and Y. Deng, "Highly ordered $\mathrm{CoFe}_{2} \mathrm{O}_{4}$ nanowires array prepared via a modified sol-gel templated approach and its optical and magnetic properties," Journal of Alloys and Compounds, vol. 552, no. 5, pp. 65-69, 2013.

[20] T. Dippong, O. Cadar, E. A. Levei et al., "Structure and magnetic properties of $\mathrm{CoFe}_{2} \mathrm{O}_{4} / \mathrm{SiO}_{2}$ nanocomposites obtained by solgel and post annealing pathways," Ceramics International, vol. 43, no. 2, pp. 2113-2122, 2017.

[21] M. Shi, R. Zuo, Y. Xu et al., "Preparation and characterization of $\mathrm{CoFe}_{2} \mathrm{O}_{4}$ powders and films via the sol-gel method," Journal of Alloys and Compounds, vol. 512, no. 1, pp. 165-170, 2012.

[22] P. Barvinschi, O. Stefanescu, T. Dippong, S. Sorescu, and M. Stefanescu, " $\mathrm{CoFe}_{2} \mathrm{O}_{4} / \mathrm{SiO}_{2}$ nanocomposites by thermal decomposition of some complex combinations embedded in hybrid silica gels," Journal of Thermal Analysis and Calorimetry, vol. 112, no. 1, pp. 447-453, 2013.
[23] M. Stefanescu, M. Stoia, T. Dippong, O. Stefanescu, and P. Barvinschi, "Preparation of $\mathrm{Co}_{x} \mathrm{Fe}_{3-x} \mathrm{O}_{4}$ oxydic system starting from metal nitrates and propanediol," Acta Chimica Slovenica, vol. 56, no. 2, pp. 379-385, 2009.

[24] T. Dippong, E. A. Levei, G. Borodi, F. Goga, and L. Barbu Tudoran, "Influence of $\mathrm{Co} / \mathrm{Fe}$ ratio on the oxide phases in nanoparticles of $\mathrm{Co}_{\mathrm{x}} \mathrm{Fe}_{3-\mathrm{x}} \mathrm{O}_{4}$," Journal of Thermal Analysis and Calorimetry, vol. 119, no. 2, pp. 1001-1009, 2015.

[25] W. Pon-On, N. Charoenphandhu, I.-M. Tang, P. Jongwattanapisan, N. Krishnamra, and R. Hoonsawat, "Encapsulation of magnetic $\mathrm{CoFe}_{2} \mathrm{O}_{4}$ in $\mathrm{SiO}_{2}$ nanocomposites using hydroxyapatite as templates: a drug delivery system," Materials Chemistry and Physics, vol. 131, no. 1-2, pp. 485-494, 2011.

[26] M. Kooti and E. Nasiri, "Phosphotungstic acid supported on silica-coated $\mathrm{CoFe}_{2} \mathrm{O}_{4}$ nanoparticles: an efficient and magnetically-recoverable catalyst for $N$-formylation of amines under solvent-free conditions," Journal of Molecular Catalysis A: Chemical, vol. 406, pp. 168-177, 2015.

[27] A. Pirouzfar and S. A. Seyyed Ebrahimi, "Optimization of solgel synthesis of $\mathrm{CoFe}_{2} \mathrm{O}_{4}$ nanowires using template assisted vacuum suction method," Journal of Magnetism and Magnetic Materials, vol. 370, pp. 1-5, 2014.

[28] X. Huang and Z. Chen, "Preparation of $\mathrm{CoFe}_{2} \mathrm{O}_{4} / \mathrm{SiO}_{2}$ nanocomposites by sol-gel method," Journal of Crystal Growth, vol. 271, no. 1-2, pp. 287-293, 2004.

[29] X.-H. Huang and Z.-H. Chen, "Sol-gel preparation and characterization of $\mathrm{CoFe}_{2} \mathrm{O}_{4}-\mathrm{SiO}_{2}$ nanocomposites," Solid State Communications, vol. 132, no. 12, pp. 845-850, 2004.

[30] A. Martucci, D. Buso, M. Guglielmi, L. Zbroniec, N. Koshizaki, and M. Post, "Optical gas sensing properties of silica film doped with cobalt oxide nanocrystals," Journal of Sol-Gel Science and Technology, vol. 32, no. 1-3, pp. 243-246, 2004.

[31] T. Dippong, E. A. Levei, O. Cadar, F. Goga, G. Borodi, and L. Barbu-Tudoran, "Thermal behavior of $\mathrm{Co}_{x} \mathrm{Fe}_{3-x} \mathrm{O}_{4} / \mathrm{SiO}_{2}$ nanocomposites obtained by a modified sol-gel method," Journal of Thermal Analysis and Calorimetry, vol. 128, pp. 39-52, 2017.

[32] Y. Liu, C. Mi, L. Su, and X. Zhang, "Hydrothermal synthesis of $\mathrm{Co}_{3} \mathrm{O}_{4}$ microspheres as anode material for lithium-ion batteries," Electrochimica Acta, vol. 53, no. 5, pp. 2507-2513, 2008.

[33] T. Dippong, E. A. Levei, C. Tanaselia et al., "Magnetic properties evolution of the $\mathrm{Co}_{x} \mathrm{Fe}_{3-x} \mathrm{O}_{4} / \mathrm{SiO}_{2}$ system due to advanced thermal treatment at $700{ }^{\circ} \mathrm{c}$ and $1000{ }^{\circ} \mathrm{c}, "$ Journal of Magnetism and Magnetic Materials, vol. 410, pp. 47-54, 2016.

[34] H. P. Klug and L. E. Alexander, X-Ray Diffraction Procedures, John Wiley \& Sons, New York, NY, USA, 2nd edition, 1974.

[35] I. Barin and O. Knacke, Thermochemical Properties of Inorganic Substances, Springer, Berlin, Germany, 1973.

[36] G. Bourcenu, "Fundamentele termodinamicii chimice," in Fundamentele termodinamicii chimice, A. I. Universitatii, Ed., Iasi, 1998. 

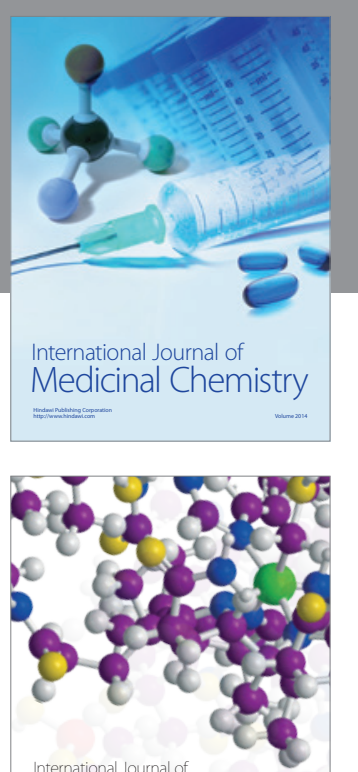

Carbohydrate Chemistry

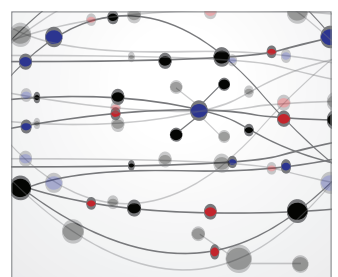

The Scientific World Journal
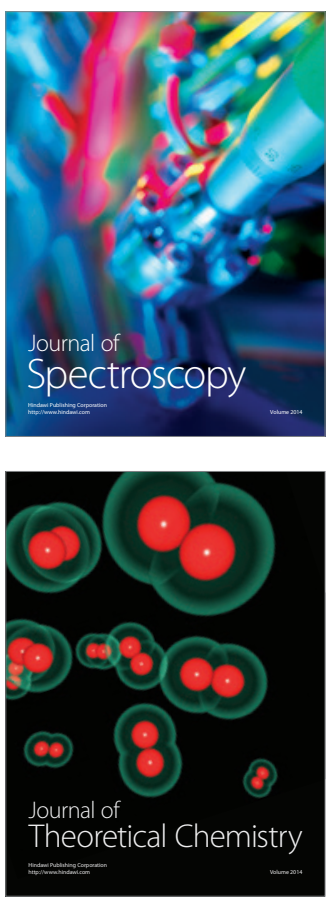
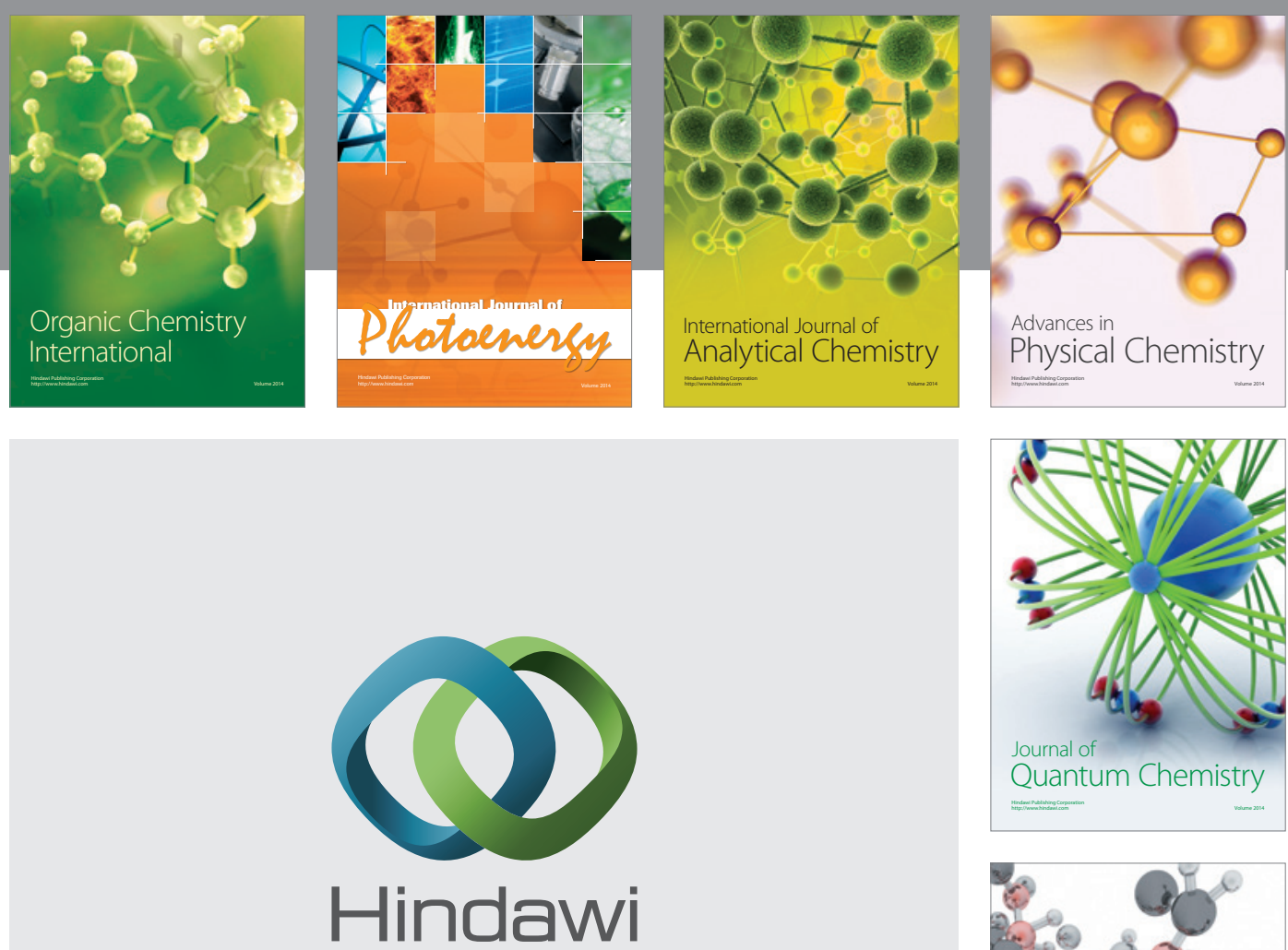

Submit your manuscripts at

https://www.hindawi.com

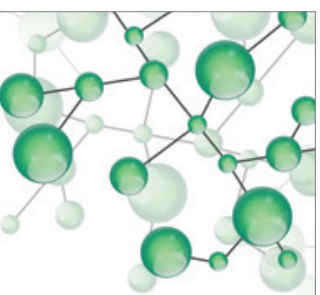

International Journal of

Inorganic Chemistry
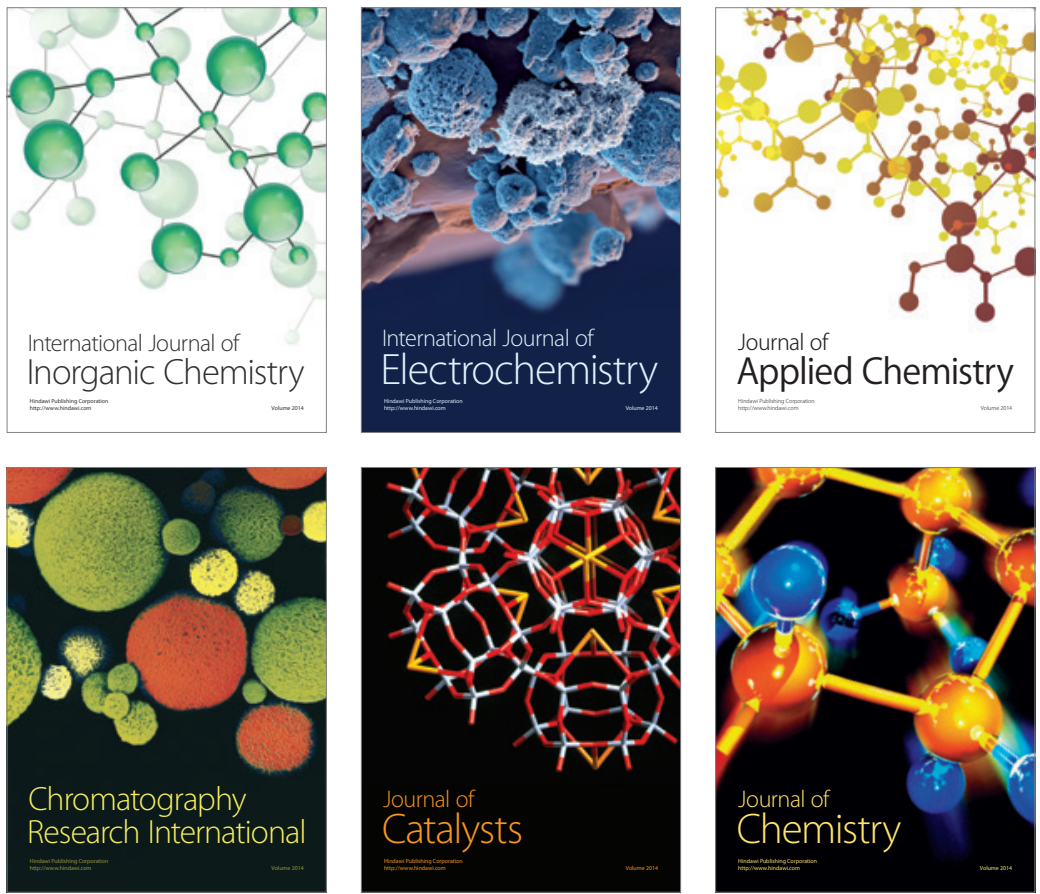

Journal of

Applied Chemistry
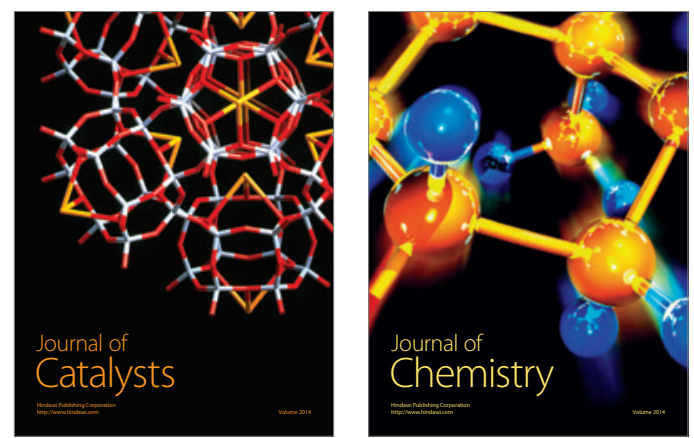
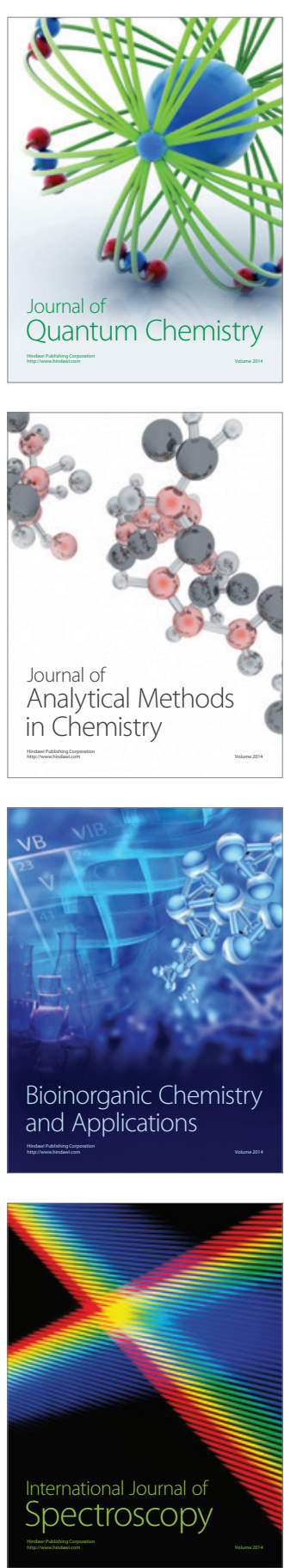